\title{
A plant test for sufficiency of phosphorus based on the phosphorus-nitrogen interaction in sunflower nutrition
}

\author{
W. Dijkshoorn and J. E. M. Lampe \\ Centre for Agrobiological Research, Wageningen, the Netherlands
}

Accepted: 4 March 1980

Key words: phosphorus fractions, depletion, restoration, $\mathrm{P}: \mathrm{N}$ ratio

\section{Summary}

Sunflower plants were alternated between complete nutrient solutions and solutions devoid of either $\mathrm{P}$ or $\mathrm{N}$. Successive harvests of top growth were analysed for $\mathrm{P}$ and $\mathrm{N}$ fractions to follow the time course of depletion and restoration.

Under adequate $\mathrm{P}$ the TCA-insoluble protoplasmic substance contained $25 \mathrm{~mol}$ $\mathrm{P}$ per $1000 \mathrm{~mol} \mathrm{~N}$. Unrestrained incorporation of $\mathrm{P}$ needed the presence of at least $25 \mathrm{~mol}$ inorganic $\mathrm{P}$ per $1000 \mathrm{~mol}$ protoplasmic $\mathrm{N}$; $\mathrm{P}$ was adequate with at least $50 \mathrm{~mol}$ of total $\mathrm{P}$ per $1000 \mathrm{~mol} \mathrm{~N}$ converted to proteins and nucleic acids.

This ratio agreed with the ratio total $\mathrm{P}$ : total $\mathrm{N}$ at which maximum growth was attained in published work of both field and pot experiments, presumably because most of the $\mathrm{N}$ was protein bound. Because of the possibility of higher contents of TCA-soluble $\mathrm{N}$, it is better that total $\mathrm{P}$ be related to the TCA-insoluble $\mathrm{N}$.

\section{Introduction}

The screening of herbage samples from arid regions required a definition of critical $\mathrm{P}$ contents which takes into account differences in $\mathrm{N}$ content between legumes and grasses. Published sufficiency ranges for maize (Jones \& Benton, 1957), soybean (Small \& Ohlrogge, 1973) and tropical grasses and legumes (Andrew \& Robbins, 1969, 1971) suggested that the plants were responsive to an increase in the $\mathrm{P}: \mathrm{N}$ ratio by weight from $<0.05$ to 0.10 at which the maximum yield was attained. Similarly soybean in field experiments attained maximum growth when the ratio of percentage $\mathrm{P}: \mathrm{N}$ in the plants was raised to 0.10 (Murali \& MollerNielsen, 1979).

In the experiments of Vanray \& van Diest (1979) with six species and P fertilizers of different availability the yield and uptakes increased with more available $P$ but the low concentration of $P$ in the dry matter (DM) remained unchanged. An analysis of $\mathbf{P}$ alone woulde have shown the plants to be equally deficient in $\mathbf{P}$. However, the uptake of $\mathrm{N}$ was restricted by its supply; this caused the tissue 
concentration of $\mathrm{N}$ to decline inversely with $\mathrm{DM}$ yield. $\mathrm{P}: \mathrm{N}$ was raised to a value nearer to that of sufficiency of $\mathrm{P}$ relative to $\mathrm{N}$.

In the study of nutrient requirements with ideas adjusted to the synthesis of plant constituents, results in moles are ofen more meaningful than percentages of DM. Since $P=31$, and $N=14$, the $P: N$ ratio by weight is 2.2 times higher than by moles.

Phosphate combines by forming esters with organic constituents. In tomato leaves $75 \%$ of the organic $P$ is insoluble in dilute acid; $80 \%$ of this insoluble $P$ is RNA-P with the remainder bound in DNA and phospholipids (Hogue et al., 1970).

The $\mathrm{P}$ retained after TCA extraction is mainly bound in nucleic acids; the $\mathrm{N}$ reflects the 'true protein' content of herbage analysis. These $\mathrm{N}$ and $\mathrm{P}$ are in the proteins, nucleic acids and phospholipids of the protoplasmic substance and the chloroplasts, nuclei, mitochondria and other cell structures. About $10 \%$ of the assimilated $N$ enters the nucleic acids (Ingle \& Hageman, 1965) and the nucleic acids have an average $P: N$ ratio by moles of 0.25 . Therefore 25 mol $P$ would be needed per $1000 \mathrm{~mol} \mathrm{~N}$ bound in the protoplasmic substance. This is close to the $\mathrm{P}: \mathrm{N}$ ratio of 0.025 in the TCA-insoluble substance of ryegrass, which was independent of changes in true protein and total $\mathbf{P}$ content of the herbage (Dijkshoorn \& Lampe, 1961).

In addition, plants contain acid-soluble $\mathrm{P}$ of which at least $70 \%$ is uncombined orthophosphate (Hogue et al., 1970). It is usually referred to as inorganic P. Well nourished maize plants contain much inorganic $\mathrm{P}$; in deficient plants it remains present at a level about equivalent to that of the organic $\mathrm{P}$ content (Sokolov, 1945). Presumably, this amount represents a threshold level of inorganic $\mathbf{P}$ below which no net synthesis of organic $P$ can take place.

The total requirements can then be given by: $25 \mathrm{~mol} P$ for the synthesis of nucleic acids plus $25 \mathrm{~mol} P$ needed to maintain the non-limiting tissue concentration of inorganic $P$, each per 1000 mol $\mathrm{N}$ bound in the protoplasmic substance. If more $\mathbf{P}$ is absorbed, the conversion to organic $\mathrm{P}$ will be controlled by $\mathrm{N}$ metabolism with the excess accumulating as inorganic P. For this reason inorganic $\mathrm{P}$ has been proposed as diagnostic for $\mathrm{P}$ sufficiency. However, the formation of inorganic $\mathrm{P}$ as an artifact during drying may render this test unreliable.

Barr \& Ulrich (1963) found that oven-drying transforms TCA-soluble organic $\mathrm{P}$ into inorganic P. This fraction is small and offers no serious problem. However, the reported 30-70 \% decomposition of the more important TCA-insoluble organic $\mathrm{P}$ would invalidate a scheme based on forms of $\mathrm{P}$ in dry plant samples. In the present work we have used more rapid over-drying which did not seem to lead to such serious discrepancies.

Agreement between the ratios total $\mathrm{P}$ : TCA-insoluble $\mathrm{N}$ and total $\mathrm{P}:$ total $\mathrm{N}$ would hold when all of the $N$ were in the proteins and nucleic acids. This is approximately true, except when higher levels of nitrate in the tissue contribute to the total $\mathrm{N}$ content, as is sometimes the case when heavy dressings of $\mathrm{N}$ have been applied.

Pegtel (1976) determined total $\mathrm{N}$ and nitrate $\mathrm{N}$ and obtained organic $\mathrm{N}$ by 
difference as a measure of the assimilated $\mathrm{N}$. His results showed that the growth rate fell off when the total $\mathrm{P}$ : organic $\mathrm{N}$ dropped below 0.050 by moles. Under severe deficiency it decreased to a minimum of 0.010 which must be related to repression of nucleinate synthesis (Lee et al., 1976), but protein synthesis from organic $\mathrm{N}$ is also repressed by $\mathrm{P}$ deficiency (Ranjan \& Balkrishna, 1963; Eaton, 1949).

Most of the available information is based on total $\mathrm{P}$ and total $\mathrm{N}$ in oven-dried samples. Perhaps the best picture of $\mathbf{P}$ partitioning is obtained from frozen and lyophilized fresh material. Work of this kind is usually concerned with small plant parts or leaves only (Lee et al., 1976; Hogue et al., 1970). In young leaves nucleic acid accumulation is ahead of protein deposition. Therefore the protoplasmic $\mathrm{F}: \mathrm{N}$ ratio may be higher that in older leaves and whole plant tops.

\section{Experimental}

Nutrient solutions. Four types of test solution were prepared: The complete solu-

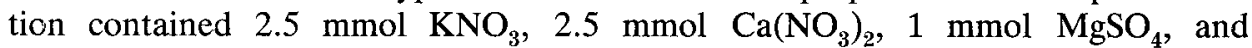
$0.5 \mathrm{mmol} \mathrm{KH}_{2} \mathrm{PO}_{4}$ per litre. The P-deficient solution had the phosphate replaced by its equivalent of $\mathrm{K}_{2} \mathrm{SO}_{4}$. The $\mathrm{N}$-deficient solution had the nitrates replaced by their equivalent of $\mathrm{SO}_{4}$. In addition a solution deficient of $\mathrm{P}$ and $\mathrm{N}$ was prepared by substituting $\mathrm{SO}_{4}$ for both the nitrates and the phosphate in the schedule. Trace elements and complexed Fe were added to all the solutions.

The test plants. Sunflower (Helianthus annuus L.) was used as the experimentai plant of which the symptoms of $\mathrm{P}$ deficiency have been described by Eaton (1949). Seeds of the cv. INRA 6501 were germinated in perlite, one seedling was transplanted to each pot holding one litre of the complete untrient solution. When the plants had established and were large enough they were subjected to the various treatments.

\section{Treatments}

Experiment 1. At day 0 the pots were emptied. One half of the plants received the fresh complete medium as the control; the other half the solution deficient of P. At time intervals of a few days separate sets of plants were removed from the culture and the tops were harvested. The material was dried within a few hours in a forced-draught oven at $90^{\circ} \mathrm{C}$, stored in paper bags at $100^{\circ} \mathrm{C}$ in a drying cabinet overnight, then weighed, ground, and stored for analysis.

During the test the solutions were frequently renewed to avoid exhaustion of the supplied nutrients.

Experiment 2. In this experiment one half of the plants were depleted of $\mathbf{P}$ in advance by growing then for a while on the test solution without P. At day 0 they were transferred to the complete nutrient solution. Supplied with one litre, each plant received $0.5 \mathrm{mmol} \mathrm{P}$. The solution was not renewed in order to effect a 
pulse treatment with a single dose, adjusted to plant size so as to cause a temporary measurable increase in plant $\mathbf{P}$, superimposed on the gradual exhaustion of the other nutrients, mainly $\mathrm{N}$.

The other half of the plants received complete nutrition until they were transferred at day 0 to the test solution without P. Again the solution was not renewed in order to achieve comparable rates of exhaustion of $N$. From day 0 onward a number of plants were harvested at intervals of a few days to obtain sufficient material for analysis. The material was dried as described above.

Experiment 3. Young plants of $0.5 \mathrm{~g}$ dry weight were placed on the test solution without $P$ and without $N$. Sets of plants were harvested at 0,5 and 8 days of growth without $P$ and $N$. After 8 days the remaining plants were given the test solution with $\mathrm{N}$ but without $\mathrm{P}$ and the sampling was continued at intervals of a few days.

\section{Plant analysis}

Total $\mathrm{N}$ was determined with a salicylaîe-amended Kjeldahl procedure, nitrate $\mathrm{N}$ with a xylenol procedure. The difference was recorded as organic $\mathrm{N}$ (NORG).

For TCA-insoluble N $1 \mathrm{~g}$ was extracted with $40 \mathrm{ml}$ ice-cold $5 \%$ TCA. The residue was washed with another $40 \mathrm{ml}$ cold TCA and analysed for $\mathrm{N}$ by Kjeldahl method. It is referred to as protoplasmic N and denoted by PRON.

For TCA-insoluble $P$ the residue was placed in a $50-\mathrm{ml}$ beaker and dried on a hot place at $130{ }^{\circ} \mathrm{C}$. The beaker was then placed in a cold muffle furnace, slowly heated to $550^{\circ} \mathrm{C}$ and ashed for three hours. The ash was treated in sequence with a few $\mathrm{ml}$ of nitric and hydrochloric acid, each time expelling the acid on the hot plate. The ash was dissolved in 5\% TCA and filtered; P was measured by the method of Lowry \& Lopez (1946). This represented the P bound in the nucleic acids associated with the 'true protein', called protoplasmic $\mathbf{P}$ and denoted by PROP.

The TCA extract and washings were collected and made up to $100 \mathrm{ml}$ with cold $5 \%$ TCA, then analysed for free inorganic orthoposphate by the method of Lowry \& Lopez (1946). This fraction represents inorganic P, abbreviated to INP.

Total $\mathbf{P}$ was determined after direct dry ashing of $0.5 \mathrm{~g}$ plant material in a glass beaker as described for PROP. For check samples the values were some $5 \%$ lower than those obtained by wet ashing and a Fiske-Subbarov procedure used as a routine in the Institute for total $P$; they were recorded under TOP.

Contents of TCA-soluble organic $\mathrm{P}$ were small compared with inorganic $\mathrm{P}$ in the extract; the summed values of INP and PROP were equal to TOP within $10 \%$.

\section{Results and discussion}

Experiment 1: switching to $P$ deficiency

The growth curves are shown in Fig. 1. The plants in $\mathbf{P}$ deficient medium grew 


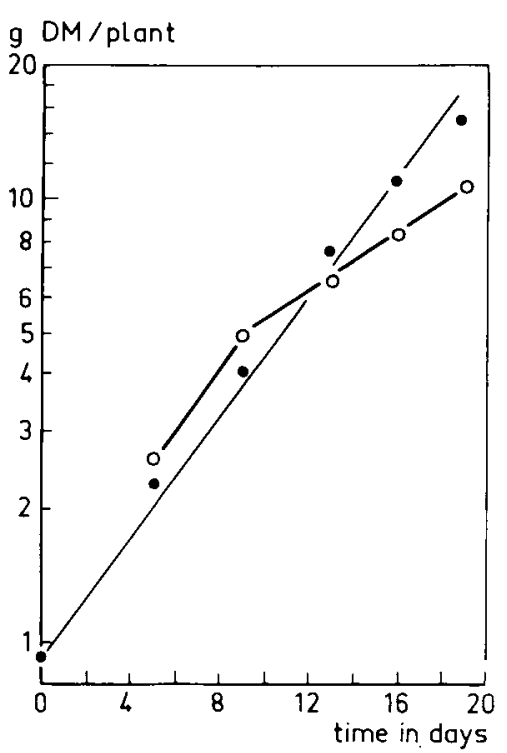

Fig. 1. Dry weight per plant versus time. Solid dots: on complete medium. Open dots: $P$ removed from the supply at zero time.

fast during the first 8 days, but markedly slower when deprived of $P$ for more then 10 days. The breakpoint in the slope of the curve shows that the relative growth rate decreased at the $5 \mathrm{~g}$ DM level when the dry weight had increased by fivefold.

In Fig. 2 the $\mathrm{P}$ contents per plant are plotted against the dry weight. The unequal relative increments resulted in curvilinear relationships. In the control plants this corresponded to a decrease in concentration in the DM from initially $280 \mathrm{mmol} \mathrm{P} / \mathrm{kg} \mathrm{DM}$ to finally $140 \mathrm{mmol} \mathrm{P} / \mathrm{kg}$ DM. No signs of malnutrition occurred as $\mathrm{P}$ remained well above the deficient level.

In the plants without $\mathrm{P}$ the shoot remained reasonably constant at $0.3 \mathrm{mmol}$ $\mathrm{P} /$ plant. Dilution by growth reduced the initial $280 \mathrm{mmol} \mathrm{P} / \mathrm{kg} \mathrm{DM}$ to only $30 \mathrm{mmol} \mathrm{P} / \mathrm{kg} \mathrm{DM}$ at the last sampling date. At the $5 \mathrm{~g}$ DM level at which the relative growth rate decreased, $P$ had dropped to $60 \mathrm{mmol} P / \mathrm{kg} \mathrm{DM}$ at which the nutrient became limiting.

The test solutions were equal in nitrate content and were renewed at the same frequency so that the cumulative inputs of $\mathrm{N}$ with and without $\mathrm{P}$ supply were equal. The yields of organic N(NORG) and protoplasmic N(PRON) were similar at the start of the experiment. After the critical $5 \mathrm{~g}$ DM shoot weight the production of NORG and PRON slowed down in the P deficient treatment more than under adequate $P$ (Fig. 3). The difference in height and in slope of the curves indicates that the repression involved the amounts per plant as well as per unit DM produced.

The main characteristic of this inhibition was a reduced conversion of the assimilated $\mathrm{N}$ into protoplasmic $\mathrm{N}$. Under adequate $\mathrm{P}$ the amount of PRON per plant increased with a constant conversion of NORG into PRON of $90 \%$. With 

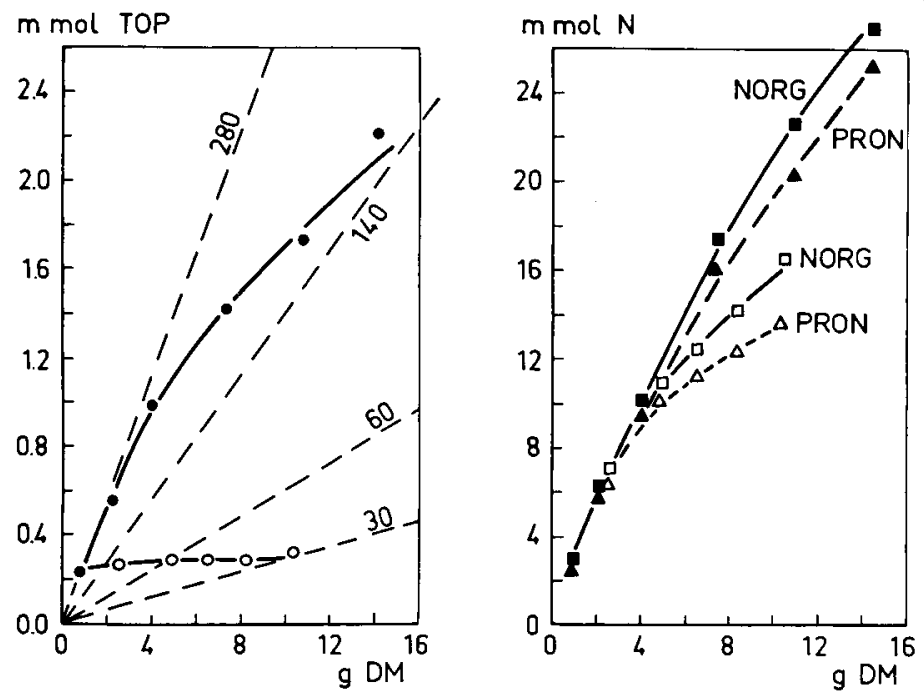

Fig. 2 (left). The relationship between total $P$ (TOP) per plant and the dry weight. Solid dots: with $\mathbf{P}$, open dots: without $\mathbf{P}$ in the supply. The dashed lines indicate tissue concentration levels in $\mathrm{mmol} / \mathrm{kg} \mathrm{DM}$ as indicated by the figures.

Fig. 3 (right). The relationship between organic $N$ (NORG) and protoplasmic N (PRON) contents per plant and the dry weight. The open symbols refer to the P-deficient medium.

$P$ deficiency it slowed down until at the conclusion of the test the plant had $80 \%$ of the organic $\mathrm{N}$ in the form of TCA-insoluble protoplasmic N (Fig. 4).

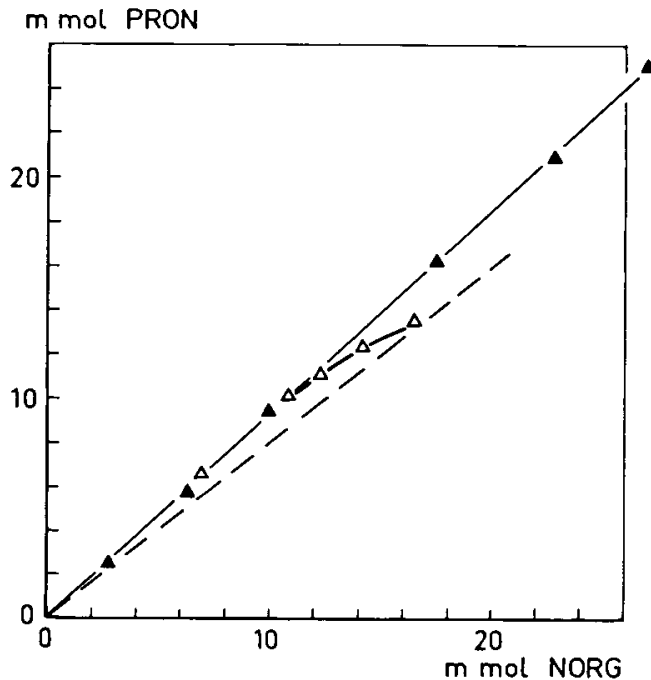

Fig. 4. The relationship between protoplasmic N (PRON) and organic N (NORG) contents per plant. The open symbols are for the P-deficient plants. 
The successive outputs of PROP are shown in Fig. 5 in relation to those of PRON. Under adequate $\mathrm{P}$ the amounts per plant increased with the growth at a constant PROP : PRON ratio of about 0.023. At the beginning of the test all plants contained $2.4 \mathrm{mmol}$ PRON and $0.06 \mathrm{mmol}$ PROP per plant; five days later, at the second sampling date, they had formed another $0.1 \mathrm{mmol}$ PROP with the PROP : PRON ratio unchanged and PRON raised to $6 \mathrm{mmol} /$ plant. From then on the synthesis of PROP was arrested in the P deficient plants while PRON continued rising with a decrease in the ratio to a final low value of about 0.012 . During this phase the plants were deficient; the relative growth rate decreased and later necrotic spots appeared on the older leaves.

Where the minimum ratio was attained, the points seem to level off along the line for proportionality at $P: N=0.012$. This is more clearly shown by the values for the concentrations in the DM (Fig. 6). In the P-deficient plants the concentration of the PROP decreased with age of the culture much faster than that of PRON until their ratio was stablished at 0.012 . At this level the nucleic acid moiety in the protoplasmic substance had declined to half its normal proportion as a minimum content at which protein synthesis was arrested. As a result lower levels of PRON in the DM were attained than in the plants with a constantly maintained supply of $P$.
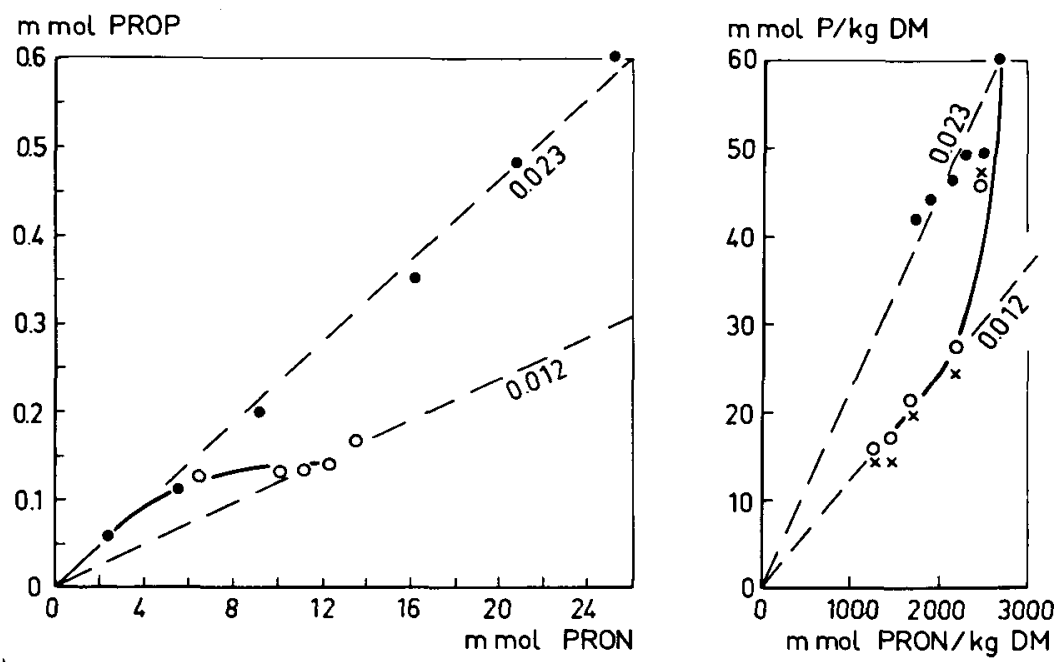

Fig. 5 (left). The relationship between the protoplasmic $\mathbf{P}$ (PROP) and the protoplasmic $\mathbf{N}$ (PRON) contents per plant. The open dots refer to the P-deprived plants.

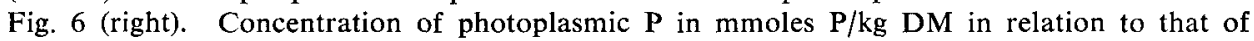
protoplasmic $\mathrm{N}$ in mmoles $\mathrm{N} / \mathrm{kg}$ DM during the growth on complete medium (solid dots) and on the medium without $\mathbf{P}$ (open dots). The concentrations decreased with the duration of growth. The dashed lines indicate the normal PROP : PRON (0.023) and the deficient $(0.012)$ content ratios. The crosses indicate the tissue concentration of inorganic $P$ in the $P$-deficient plant. 
During the growth of the $\mathrm{P}$-deficient plants inorganic $\mathrm{P}$ remained present at a level equivalent to the PROP content; the starved plants had no ability to further convert INP to PROP. INP in the well nourished plants (not shown in Fig. 6) remained af few times in excess of their PROP content.

The tissue concentrations of the constituents are related to the yield of DM in Fig. 7. The need to emphasize relative changes makes equal logarithmic scales the most convenient means to interprete these results.

With no change in total $\mathrm{P}$ per plant in the P-deprived treatment, the concentration of TOP in the DM decreased in inverse proportion with dry weight (Fig. 7a). Between the first and second harvest date INP decreased relatively faster; PROP was relatively slower than TOP in concentration because INP was converted to PROP with corresponding changes in their contents per plant. Conversion was arrested where INP equalled PROP, and their concentrations continued to decline in inverse proportion with the yield.

In this type of graph the linear distance between PROP and PRON is a measure of their ratio. Allowing for errors of $10 \%$ it has been runded to 0.025 at the beginning and 0.010 at the end of the period of growth without $\mathrm{P}$.

The results for the control plants are shown in Fig. $7 \mathrm{~b}$ and need no further elucidation.
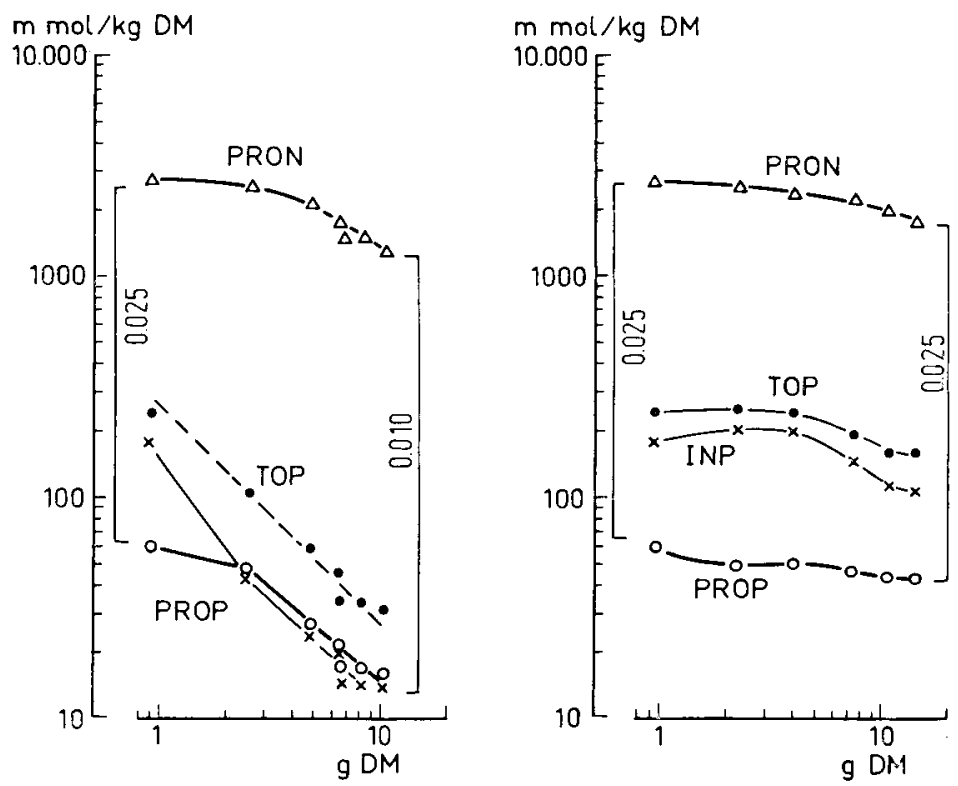

Fig. 7. Record of the measured tissue concentrations and dry weight at the successive stages of growth on the test media. Fig. 7a (left): after transfer to the P-deficient medium Fig. 7b (right): in continued supply of the complete nutrient solution. The lengths of the vertical lines correspond to the PROP : PRON ratios given as rounded values. The crosses denote inorganic $P$ (INP) concentrations in the DM. 
Experiment 2: pulse restoration of $P$

In this experiment the previously starved plants were clearly deficient in $P$ when the treatment was started. At day 0 the PROP : PRON ratio was 0.010 and the concentration of INP in the DM was equal to that of PROP (Fig. 8a). Uptake of new $\mathrm{P}$ raised the $\mathrm{P}$ content. Slower conversion to PROP caused a temporary overloading with INP at the second sampling date. PROP continued rising slowly until at day 7 the PROP : PRON ratio nearly attained the normal value of 0.025 . From then onward the pulse of new tissue $P$, resulting from uptake of the single supply, was exhausted and the synthesis of PROP was retarded; in this case by using INP from the tissue until it fell below the usual threshold level of equality to PROP. The other plant (Fig. 8b) which had received the complete nutrition and were transferred to the test medium without $P$, showed the usual picture of depletion with the older pool of inorganic $\mathbf{P}$ consumed until it equalled PROP. Because the medium was not renewed, the decline in $\mathrm{N}$ with age of the culture was accelerated by its exhaustion. This prevented the plants from becoming severely deficient of $P$; the PROP : PRON ratio remained at 0.025 .

It should be noted that in Fig. 8a the decline in PRON was temporarily reversed at the time when the tissue concentration of PROP attained its maximum. At that point the increments from day 0 were $20 \mathrm{mmol} P R O P / \mathrm{kg} D M$ and $300 \mathrm{mmol}$ PRON $/ \mathrm{kg}$ DM. Thus the $\mathrm{P}: \mathrm{N}$ ratio of the new PRON was high at 0.066 and adapted to the restoration of the initially deficient PROP : PRON ratio.
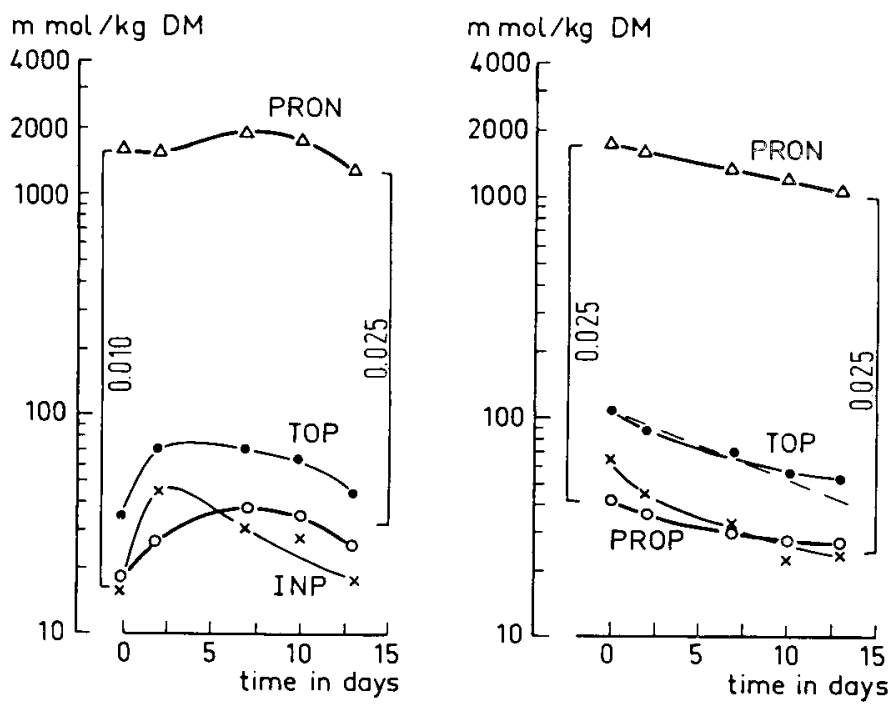

Fig. 8. Changes in tissue concentration with time from transfer of initially P-deficient plants to a single supply of the complete nutrient solution (Fig. 8a left) and of previously well nourished plants to a single supply of the medium without $\mathrm{P}$ (Fig. 8b, right). Crosses inorganic $P$ (INP). 
Since the N : $\mathrm{P}$ ratio in nucleic acids is about 4 , the increment of $300 \mathrm{mmol}$ PRON would be composed of about $80 \mathrm{mmol}$ NA-N and $220 \mathrm{mmol}$ protein N. This proves that renewed synthesis of PROP had reactivated protein synthesis as the main contributor to the increase in PRON.

Experiment 3: pulse restoration of $N$

In this experiment (Fig. 9) the formatin of PROP and PRON stopped over the period when plants were deprived of both $\mathrm{N}$ and $\mathrm{P}$. The concentrations in the tissue of PRON, INP and PROP dropped almost four times at the same relative rate with increase in DM because contents per plant remained unchanged. Because of lack of N no PROP was synthesized from INP; the concentration of INP remained threefold that of PROP. The $1.9 \mathrm{~g}$ dry weight attained at the end of this part of the test period was deficient of $\mathrm{N}$ but not of $\mathrm{P}$.

After 8 days the remaining plants were given the medium containing $\mathrm{N}$ but no $\mathrm{P}$. The concentration of PRON was rapidly restored with the resumption of $\mathrm{N}$ metabolism acting as the driving force for renewed synthesis of PROP. This drew upon the residual INP until the latter was depleted to the limiting level, equal to that of PROP. Once $P$ was depleted, the PROP : PRON ratio dropped to the deficient value of 0.010 .

At the maximum the plant had gained $1200 \mathrm{mmol}$ PRON $/ \mathrm{kg}$ DM and $20 \mathrm{mmol}$ PROP $/ \mathrm{kg} \mathrm{DM}$; the newly formed PRON was deficient in nucleic acids. From then on the PROP : PRON ratio dropped to 0.010 and the plants became severely deficient in $\mathbf{P}$.

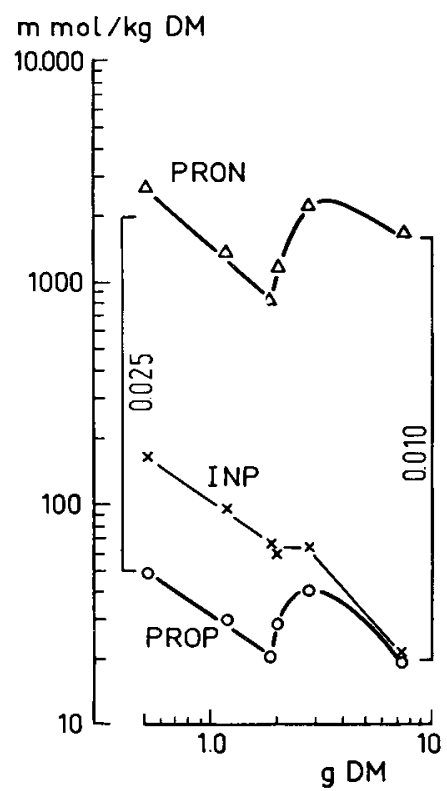

Fig. 9. Changes in tissue concentration following the transfer of the plants to the test medium without $\mathrm{N}$ and without $P$. When the dry weight had attained $1.9 \mathrm{~g} / \mathrm{plant}$ the supply of $\mathrm{N}$ was restored by transferring the remaining plants to the test solution with $\mathrm{N}$ and without $\mathrm{P}$. It was not until $\mathbf{N}$ was restored that $\mathbf{P}$ deficiency could develop. 


\section{Conclusions}

The main sink for organic $\mathrm{P}$ in sunflower plants is the $\mathrm{P}$ bound in nucleic acids of the protoplasmic substance. As bricks in the cell structure, $\mathrm{P}$ and $\mathrm{N}$ are retained at a molar $\mathrm{P}: \mathrm{N}$ ratio of 0.025 in the TCA-insoluble substance which contains the proteins and nucleic acids.

The main source of inorganic $P$ is in the TCA-soluble $P$ which is mainly free orthophosphate. When the supply by uptake is suspended, its concenration in the tissue decreases with growth and metabolism. Net synthesis of nucleic acid $\mathrm{P}$ is arrested when the concentration of inorganic $\mathrm{P}$ in the tissue has decreased to a level equal to that of the TCA-insoluble P. From then on the growth is retarded, the newly formed protoplasmic substance is deficient in nucleic acids and the $\mathrm{P}: \mathrm{N}$ ratio in the TCA-insoluble substance eventually falls to 0.010 by moles at which the plants are severely deficient in P.

The relationship showed that the demand for total $\mathrm{P}$ of healthy plants has been met when they contain 25 mol TCA-insoluble $P$ per 1000 mol TCA-insoluble $N$ and in addition, at least the same amount of inorganic $\mathrm{P}$; under adequate $\mathrm{P}$ the ratio total $\mathrm{P}$ : TCA-insoluble $\mathrm{N}$ must be higher than 0.050 by moles. Expressed in weight percentages of the elements the $\mathrm{P}: \mathrm{N}$ ratio should be at least about 0.10 by weight.

Because of the time involved to transform a reduced relative growth ratio into a measurable decrease in plant yield, a smaller growth due to $\mathrm{P}$ deficiency may be displayed at a more advanced level of depletion. The ratio total P : TCA-insoluble $\mathrm{N}$ is then a little lower than the critical ratio.

Tests for sufficiency of $\mathbf{P}$ in plant samples are best made by analysis for total $\mathbf{P}$ and TCA-insoluble $\mathrm{N}$. Samples with $\mathrm{P}: \mathrm{N}$ ratios higher than 0.050 by moles (or 0.10 by weight) can be regarded as sufficient of $P$; those with lower ratios as deficient of $\mathrm{P}$. If only total $\mathbf{P}$ and total $\mathrm{N}$ are known and the nitrate contents are small, a reasonable approximation is that about $85 \%$ of the $\mathrm{N}$ in the plant tops is insoluble in TCA.

The close relationship between $\mathrm{P}$ and $\mathrm{N}$ of which to build the protoplasmic substance has been shaped into a more general form by Linser \& Titze-Bettner (1971) in their work on P uptake and protein production during the growth of summer wheat. It may also form a basis for the interpretation of the stimulating effect of $\mathrm{N}$ application on the uptake of $\mathrm{P}$ (Bennet et al., 1953; Cole et al., 1963; Nielsen et al., 1963; Thien \& McFee 1970) and of the observation that more P in the tissue is needed to cure visual symptoms of $\mathrm{P}$ deficiency when the nitrogen content is higher (Besford, 1979).

\section{Acknowledgment}

The authors are grateful to Dr P. Gillard, Davies, Laboratory, Townsville (Qld.), Australia, for critical comments on the manuscript. 


\section{References}

Andrew, C. S. \& M. F. Robins, 1969. The effect of phosphorus on the growth and chemical composition of some tropical pasture legumes I. Growth and critical percentages of phos. phorus. Aust. J. agric. Res. 20: 655-674.

Andrew, C. S. \& M. F. Robins, 1971. The effect of phosphorus on the growth, chemical composition and critical phosphorus percentages of some tropical pasture grasses. Aust. J. agric. Res. 22: 693-705.

Barr, C. E. \& A. Ulrich, 1963. Phosphorus fractions in high and low phosphate plants. J. Agric. Food Chem. 11: 313-316.

Rennet, W. F., G. Stanford \& L. Dumenie, 1953. Nitrogen, phosphorus and potassium content of the corn leaf and grain as related to nitrogen fertilization and yield. Proc. Soil Sci. Soc. Am. 17: 252-258.

Besford, R. T., 1979. Uptake and distribution of phosphorus in tomato plants. Pl. Soil 51: 331-340.

Cole, C. V., D. L. Grunes, L. K. Porter \& S. R. Olson, 1963. The effect of nitrogen on shortterm phosphorus absorption and translocation in corn. Proc. Soil Sci. Am. 27: 671-674.

Dijkshoorn, W. \& J. E. M. Lampe, 1961. Phosphorus fraction in perennial reygrass. Jaarb. Inst. biol. scheik. Onderz. Landgewassen 1961: 101-106.

Eaton, S. V., 1949. Effects of phosphorus deficiency on growth and metabolism of sunflower. Bot. Gaz. 110: 449-464.

Hogue, E., G. E. Wilcox \& D. J. Cantliffe, 1970. Effect of soil phosphorus levels on phosphate fractions in tomato leaves. J. Am. Soc. Hort. Sci. 95: 174-176.

Ingle, J. \& R. H. Hageman, 1965. Metabolic changes associated with the germination of corn II. Nucleic acid metabolism. Pl. Physiol. 40: 48-53.

Jones, J. \& J. Benton, 1967. In: Soil testing and plant analysis, p. 49-58. Soil Science Society of America, Madison. Wis.

Lee, K. W., A. C. Caldwell \& C. E. Clapp, 1966. RNA, DNA and other phosphorus fractions in soybeans as affected by high phosphorus nutrition. Pl. Soil 25: 406-412.

Lee, K. W., C. E. Clapp \& A. C. Caldwell, 1976. Phosphor compounds in soybeans as affected by phosphorus levels in solution. Pl. Soil 44: 475-479.

Linser, H. \& L. Titze-Bettner, 1971. Phosphataufname und System-(Protein) Syntheseleistung bei Sommerweizen. Z. PflErnähr. Bodenkd. 128: 235-242.

Lowry, O. H. \& J. A. Lopez, 1946. The determination of inorganic phosphate in the presence of labile phosprate esters. J. Biol. Chem. 162: 421-428.

Murali, N. S. \& J. Moller Nielsen, 1979. Evaluation of $\mathrm{N}$ and $\mathrm{P}$ nutritional status of soybean by plant analysis. Commun. Soil Sci. Pl. Anal. 10: 673-688.

Nielsen, K. F., R. B. Carlson and I. Hoffman, 1963. A study of the ion interactions in the uptake of N, P, K, Ca, Cl and S by corn. Soil Sci. 95: 315-321.

Pegtel, D. M., 1976. On the ecology of two varieties of Sonchus arvensis. Thesis, University of Groningen, $148 \mathrm{pp}$.

Ranjan, S. \& M. Balkrishna, 1963. Effects of phosphorus deficiency on the free and protein bound amino acids of linseed plants. Flora 152: 399-408.

Small, H. G. and A. J. Ohlrogge, 1973. In: Soil testing and plant analysis, p. 315-327. Soil Science Society of America, Madison, Wis.

Sokolov, A. V., 1945. Influence of feeding conditions upon the plant's content of various phosphorus compounds. C. R. (Doklady) Ac. Sci. USSR 49: 123-126.

Thien, S. J. \& W. W. McFee, 1970. Influence of nitrogen on phosphorus absorption and translocation in Zea mays. Proc. Soil Sci. Soc. Am. 34: 87-90.

Vanray, B. \& A. van Diest, 1979. Utilization of phosphate from different sources by six plant species. Pl. Soil 51: 577-589.

Viets, E. G., C. E. Nelson \& C. L. Crawford, 1954. The relationship among corn yields, leaf composition, and fertilizers applied. Proc. Soil Sci. Soc. Am. 18: 297-301. 